\title{
Pelaksanaan Fungsi Dinas Koperasi Perindustrian dan Perdagangan dalam Pemberdayaan Usaha Kecil Menengah Agribisnis
}

\author{
Miranti $^{1^{*}}$, Roby Satria ${ }^{2}$
}

This article is an open access article distributed under the terms and conditions of the Creative Commons Attribution-ShareAlike 4.0 International (CC BY SA ) License (https://creativecommo ns.org/licenses/bysa/4.0/).

\section{Jurnal Politik dan} Pemerintahan Daerah ISSN 2686-2271

Fakultas Ilmu Sosial dan Ilmu Politik, Universitas Muara Bungo Jl. Diponegoro No. 27, Muara Bungo-Jambi, (0747) 323310

\author{
${ }^{1}$ Program Studi Ilmu Pemerintahan Fakultas Ilmu Sosial Dan Ilmu Politik, Universitas \\ Muara Bungo, Kabupaten Bungo, Provinsi Jambi \\ 2 Program Studi Ilmu Pemerintahan Fakultas Ilmu Sosial Dan Ilmu Politik, Universitas \\ Muara Bungo, Kabupaten Bungo, Provinsi Jambi \\ * Correspondence Author: umbmiranti@gmail.com
}

Abstract: Abstract: UMKM, industry and trade in Bungo Regency as the agency responsible for empowering UMKM are obliged to empower UMKM in Bungo Regency, especially agribusiness UMKM so that they can continue to develop and become more independent. The Department of Industry and Trade has the main task of carrying out regional government affairs based on autonomy and auxiliary tasks in the field of industry and trade in accordance with the authorities and policies of the regional government. This study uses a qualitative descriptive method, namely research conducted to determine the value of independent variables, either one or more variables without making comparisons or connecting between one variable and another. The informants in this study were the head of the Bungo Regency Kopperindag Service, the Head of Small and Medium Enterprises (UKM), the Head of the UMKM Capital and Partnership Relations Section, and two UMKM staff, apart from environmental officials from the Kopperindag Service. two informants who come from agribusiness UMKM owners. As for the results of this study, it can be seen that the implementation of the functions of the cooperative, UMKM, Industry and trade offices in Bungo Regency in empowering agribusiness UMKM is to provide guidance, counseling, education and training as well as development assistance in the form of providing capital to agribusiness UMKM owners while the inhibiting factors are: causing the lack of functioning of the Kopperindag service, among others, not conducting outreach to the general public, the lack of coordination with the manpower office and the service in charge of agriculture and the limited apparatus of the Kopperindag service itself.

Keywords: the function of local government, the realization of the implementation and empowerment of UMKM

Abstrak: UMKM, perindustrian dan perdagangan kabupaten bungo sebagai instansi yang bertanggungjawab dalam pemberdayaan UKM berkewajiban untuk melakukan pemberdayaan UKM di Kabupaten Bungo khususnya UKM agribisnis agar dapat terus berkembang dan menjadi lebih mandiri. Dinas perindustrian dan perdagangan mempunyai tugas pokok melaksanakan urusan pemerindah daerah berdasarkan atas otonomi dan tugas pembantu dibidang perindustrian dan perdagangan sesuai dengan kewenangan dan kebijakan pemerintah daerah. Penelitian ini menggunakan metode desktiptif kualitatif yaitu penelitian yang dilakukan untuk mengetahui nilai variable mandiri, baik satu variable atau lebih tanpa membuat perbandingan atau menghubungkan antara variable satudengan yang lain. Adapun yang menjaadi informen dalam pnelitian ini adalah, kepala dinas kopperindag kabupaten bungo 
kepala badan usaha kecil dan menengaah (UKM), kepala seksi permodalan dan hubungan kemitraan UMKM, dan dua orang staf bidang UMKM, selain dari pejabat lingkungan dinas Kopperindag, dalam peneliti ini ada dua orang informen yang berasal dari pemilik UKM agribisnis. Adapun hasil dari penelitian ini, terlihat pelaksanaan fungsi dinas koperasi, UMKM, Perindustrian dan perdagangan kabupaten bungo dalam pemberdayaan UKM agribisnis adalah dengan mengadakan bimbingan, penyuluhan, pendidikan dan latihan serta bantuan pengembangan yang berupa pemberian modal kepada pemilik UKM agribisnis sedangkan faktor-faktor penghambat yang menyebabkan kurang berfungsinya dinas kopperindag antara lain tidak dilaksanakan penyuluhan kepada masyarakat umum, masih kurangnya koordinasi dengan dinas ketenagakerjaan dan dinas yang membidangi masalah pertanian serta terbatasnya aparat dari dinas kopperindag itusendiri

Kata Kunci: fungsi pemerintah daerah, terwujudnya pelaksanaan dan pemberdayaan UKM

\section{Pendahuluan}

Pembangunan nasional pada hakekatnya merupakan pembangunan manusia indonesia seutuhnya dan pembangunan masyarakat indonesia seluruhnya. Sehingga, pembangunan harus dilaksanakan secara merata ditanah air dan tidak hanya diberlakukan untuk beberapa golongan tertentu atau sebagian masyarakat tertentu saja. Hal ini bertujuan untuk mewujudkan masyarakat yang adil dan makmur berdasarkan pancasila dan undang-unndang dasar 1945. Upaya dalam meningktatkan pembangunan untuk peningkatan taraf hidup masyarakat yaitu dengan memberikan berbagai pelayanan seperti : pelayanan kesehatan, pendidikan, perekonomian, pendapatan dan lain sebagainya. Untuk mencapai keberhasilan pembangunan dibutuhkan manusia berkualitas, sumber dana yang memadai dan kekayaan atau potensi alam mendukung (Moenir, 2001)

Salah satu cara mewujudkan pembangunan adalah melalui peningkatan disektor perekonomian. Sektor perekonomian ini dapat diwujudkan melalui salah satunya adalah meningkatkan dibidang industri dan perdagangan sebagai penggerak utama proses industrialisasi sekaligus ujung tombak menghadapi globalisasi. Selain itu diperlukan pembangunan industri dan perdagangan yang berwawasan lingkungan dan berkelanjutan serta bercirikan persaingan sehat dalam rangka pemenuan kebutuhan pokok masayarakat, peningkatan nilai tambah, pengembangan kewirausahaan dan penyerapan tenaga kerja. Perdagangan dan perindustrian di indonesia ini dilaksanakan oleh setiap daerah. Menurut UndangUndang nomor 32 tahun 2004, seperti diketahui indonesia sedang menjalani masamasa awal pemerintahan yang bercorak desentralistik, dalam hal ini lebih sering dikenal dan disebut sebagai era otonomi daerah. Selain dari undang-undang Nomor 32 Tahun 2004 tentang pemerintahan daerah, Undang-undang nomor 33 tahun 2004 Tentang perimbangan keuangan antara Pusat dan Daerah yang tujuan pokoknya adalah memberikan keleluasaan pada daerah untuk mengurus rumah tangganya sendiri serta memberikan perimbangan yang baik antara keuangan pusat dan daerah dengan meningkatkan dan memberdayakan kemampuan perekonomian daerah masing-masing. (Widjaja, 2008). Otonomi daerah memberikan langkah-langkah provisional agar pendapat dan ide masyarakat Indonesia di daerah dapat didengar untuk pembangunan Indonesia di masa depan (Seymour \& Turner, 2002).

Dengan demikian, setiap daerah dapat mengupayakan tindakan-tindakan produktif yang dapat memacu peningkatan Pendapatan Asli Daerah (PAD), salah satunya dengan pemberdayaam Usaha Kecil Menengah dimasing-masing daerah. Pemberdayaan UKM merupakan salah satu cara untuk mengatasai krisis ekonomi, 
sedikit-banyak keberadaan UKM dapat membantu mengatasi pengangguran (Kristiyanti, 2012). Dengan adanya pemberdayaan tersebut dapat membuat UKM untuk lebih dan memacu tumbuhnya usaha-usaha lainnya. Dinas Perindustrian dan Perdagangan (Disperindag). mempunyai tugas pokok melaksanakan urusan pemerintahan daerah berdasarkan asas otonomi dan tugas pembantuan di bidang Perindustrian dan Perdagangan sesuai dengan kewenangan dan kebijakan Pemerintah Daerah. Untuk menyelenggarakan tugas pokok tersebut,

Dinas Perindustrian dan Perdagangan mempunyai fungsi sebagai berikut:

a. Perumusan kebijakan teknis dibidang koperasi, UKM, perindustrian dan perdagangan.

b. Penyelenggaraan urusan pemerintahan dan pelayanan umum dibidang kopeasi, UKM, perindustrian dan perdagangan.

c. Pembinaan dan pelaksanaan tugas dibidang koperasi, UKM, perindustrian dan perdagangan.

d. Pelaksanaan tugas lain yang diberikan oleh bupati.

Sedangkan tujuan Dinas Koperasi, UMKM, Perindustrian dan Perdagangan antara lain:

1. Meningkatkan kesadaran perilaku usaha dan koperasi untuk merubah pola kerja yang lebih produktif

2. Meningkatkan kualitas dan kuantitas produksi/komoditi yang memenuhi permintaan pasar/konsumen

3. Meningkatkan penguasaan bidang tugas aparatur Pembina

4. Meningkatkan interaksi yang positif dengan pihak Legislatif, dan

5. Pengumpulan dan Penyusunan Data Base

Untuk mensukseskan usaha agribisnis, setidaknya ada 3 peran utama yang dibina dan diberi kesempatan yang terbuka, yaitu :

1. Pengembangan sektor usaha agribisnis unggulan

2. Menumbuhkan kemitraan dan peluang usaha bagi jutaan unit usaha agribisnis di perkotaan dan pedesaan untuk sektor usaha unggulan tersebut.

3. Membina dan mengembangkan saran penunjang usaha, termasuk usaha simpan pinjam/perbankan, pedoman studi kelayakan dan konsultan pendamping.

Prospek komoditi agrobisnis nasional masih cukup menjanjikan dengan melihat beberapa indikator penting, yaitu :

1. Usia angkatan kerja mencapai sepertiga dari seluruh penduduk Indonesia berpotensi dapat meningkatkan komoditas agribisnis.

2. Jumlah perusahaan skala kecil masih sehat masih kurang sekali dberbagai sentra produksi, terutama yang telah memperoleh fasilitas kredit perbankan.

3. Para pengelola agribisnis di Indonesia masih kurang selektif dalam memilih produk unggulan dan kesesuaian lahannya, sehingga masih perlu diberdayakan.

4. Masih tumbuhnya kesadaran masyarakat untuk mengkonsumsi produk agribisnis lokal di pasar-pasar / secara langsung dengan harga terjangkau

5. Masih tersediamya lahan yang cukup diberbagai daerah yang sedang menggalakan sektor agribisnis sebagai produk unggulan daerah 
6. Minat wirausaha dikalangan usaha kecil dan generasi muda makin besar, yang sekaligus menjadi potensi calon pelaku bisnis baru masih besar. (http://id.m.wikipedia.org/wiki/prospek agribisnis).

Kabupaten Bungo merupakan salah satu benntuk perwujudan dari pelaksanaan otonomi daerah yang harus dilakukan dalam pengembangan potensi sumber daya yang tesedia. Salah satunya adalah dalam bidang Usaha Kecil Menengah atau disingkat dengan UKM. Bila dilihat sepintas, UKM di Kabupaten Bungo ini sangatlah banyak dan selalu meningkat jumlahnya dari tahun ke tahun. Untuk lebih jelasnya mengenai data jumlah UKM di Kabupaten Bungo, dapat dilihat pada tabel di bawah ini

Tabel 1. Jumlah UKM di Kabupaten Bungo 2015-2017

\begin{tabular}{l|l|l} 
No & Tahun & Jumlah UKM \\
1 & 2018 & 2.811 \\
2 & 2019 & 3.387 \\
3 & 2020 & 3.821
\end{tabular}

Sumber : Dinas Kopperindag Kabupaten Bungo

Dari tabel di atas, dapat dilihat jumlah UKM di Kabupaten Bungo dari tahun 2018 sampai 2020, di Tahun 2018 jumlah 2.811(dua ribu empat ratus lima puluh tiga), ditahun 2019 meningkat menjadi 3.387(dua ribu delapan ratus tiga puluh satu) dan ditahun 2020 meningkat lagi dengan jumlah keseluruhan 3821 (tiga ribu delapan ratus dua puluh satu) Unit Usaha UKM. Dari berbagai jenis UKM sebagaimana dijelaskan pada tabel di atas, salah satu jenis UKM yang ada di Kabupaten Bungo, yaitu UKM Agribisnis, menurut data penulis dapatkan dari Dinas Kopperindag, bahwa UKM Agribisisnis di Kabupaten Bungo tidak eksis dan tidak berkembang dibanding dengan jumlah UKM yang ada, hal ini dapat dilihat dari jumlah UKM Agribisnis dari tahun 2018 sampai tahun 2020, untuk lebih jelas tertera tabel dibawah ini.

Tabel 2. Jumlah UKM Agribisnis di Kabupaten Bungo 2018-2020

\begin{tabular}{l|l|l|l} 
No & Tahun & Jenis & Jumlah UKM Agribisnis \\
1 & 2018 & 3 & 10 \\
2 & 2019 & 3 & 14 \\
3 & 2020 & 3 & 14
\end{tabular}

Sumber : Dinas Kopperindag Kabupaten Bungo Tahun

Tabel di atas menunjukan dari data UKM Agribisnis dari tahun 2018 terdapat UKM 3 Jenis dan 10 Jumlah UKM, di tahun 2019 hanya bertambah UKM Agribisnis dengan jenis tetap UKM Agribisnis, di tahun 2020 sama seperti di Tahun sebelumnya, yaitu terdiri dari jenis UKM Agribisnis tersebut yaitu pisang sale, jamur tiram dan tahu tempe, untuk lebih lengkap mengenai data terakhir UKM Agribisnis yaitu Tahun 2018, dapat dilihat seperti tertera pada tabel 3 dibawah ini.

\begin{tabular}{l|l|l|l}
\multicolumn{3}{|c}{ Tabel 3. Data Jumlah UKM Agribisnis di Kabupaten Bungo 2018} \\
No & Nama UKM Agribisnis & Jumlah & Tempat \\
1 & Pisang Sale & 30 & $\begin{array}{l}\text { Purwo Bakti, } \\
\text { Kec Bathin III } \\
2\end{array}$ \\
3 & Jamur Tiram & 1 & Kuamang Kuning \\
& Tahu Tempe & 60 & Cadika, Rimbo Tengah
\end{tabular}

Sumber : Dinas Kopperindag Kabupaten Bungo

Dari data di atas, jelas bahwa UKM Agribisnis sangat sedikit dibandingkan jumlah UKM secara keseluruhan yang mencapai 3821 UKM. Sedangkan dalam pengembangann dan pembinaan UKM termasuk didalamnya UKM Agribisnis 
merupakan tugas pokok dan fungsi dari Dinas Koperaasi, UMKM, Perindustrian dan Perdagangan, hal ini diatur dalam Peraturan Daerah Kabupaten Bungo Nomor 2 tahun 2011 tentang Pembentukan dan Susunan Organisasi Dinas Daerah, dalam Pasal 21 Perda tersebut menjelaskan bahwa Dinas Koperasi, UMKM, Perindustrian dan Perdagangan mempunyai tugas melaksanakan urusan pemerintahan berdasarkan asas otonomi daerah tugas pembantuan dibidang Koperasi, UMKM, Perindustrian dan Perdagangan.

Dalam menjalankan tugas Dinas Kopperindag mempunyai fungsi, adapun fungsinya masih diatur oleh pasal 21 Peraturan Daerah tersebut. Diantaranya :

a. Perumusan kebijakan teknis dibidang Koperasi, UMKM, Perindustrian dan Perdagangan

b. Penyelenggaraan urusan pemerintahan dan pelayanan umum dibidang Koperasi, UMKM, Perindustrian dan Perdagangan.

c. Pembinaan dan pelaksanaan tugas dibidang Koperasi, UMKM, Perindustrian dan Perdagangan

d. Pelaksanaan tugas lain diberikan oleh Bupati

Berdasarkan uraian diatas, maka peneliti tertarik untuk melaksanakan penelitian dengan judul "Pelaksanaan Fungsi Dinas Kopperindag Dalam Pemberdayaan Usaha Kecil Menengah Agribisnis Di Kabupaten Bungo"

\section{Pembahasan}

\section{Kondisi UKM Agribisnis di Kabupaten Bungo}

Fenomena gerakan sosial dewasa ini cukup dinamis, terlihat dari kemunculan mereka yang, baik sudah terlembaga dengan baik maupun yang bersifat sporadis. Namun, terpenting adalah bahwa gerakan sosial membawa misi tertentu, yakni adanya perubahan di dalam masyarakat yang lebih baik dan tentunya demokratis. Tak jarang, mereka justru menjadi pionir bagi perubahan yang bersifat radikal dan fundamental. Mereka berjalan dalam sebuah tuntutan perubahan terhadap kondisi yang dinilai buruk dan sewenang-wenang. Salah satu gerakan sosial yang paling dikenal adalah gerakan mahasiswa. Mereka menjadi bagian penting di dalam mengkerangkai tatanan sosial politik di banyak negara, termasuk Indonesia. Reformasi yang terjadi pada 1998 merupakan buah karya dari gerakan mahasiswa yang menginginkan terjadinya demokratisasi secara benar.

Sebelum membahas tentang kondisi UKM Agribisnis, terlebih dahulu penulis memaparkan tentang kondisi UKM agribisnis, dimana berdasarkan data dari Dinas Kopperindag tingkat perembangan usaha kecil menengah menunjukkan peneingkatan dari tahun ketahun. Hal ini dapat dilihat dalam tabel dibawah ini:

Tabel 4. jumlah UKM DI Kabupaten Bungo 2018-2020

\begin{tabular}{c|c|c} 
No & Tahun & Jumlah UKM \\
1. & 2018 & 2.811 \\
2. & 2019 & 3.387 \\
3. & 2020 & 3.821
\end{tabular}

Sumber : Dinas Kopperindag Kabupaten Bungo Tahun 2018

Dari tabel diatas, dapat dilihat jumlah UKM diabupaten bungo dari tahun 2018 sampai 2020, ditahun 2018 jumlahnya 2.811, ditahun 2019 meningkat menjadi 3.387 dan ditahun 2020 meningkat lsgi dengan jumlah keseluruhan 3821 unit usaha UKM. Untuk lebih jelasnya persentase peningatan UMK dikabupaten bungo dijelaskan pada grafik dibawah ini: 
Grafik 1. Persentase peningkatan UKM tahun 2018 -2020

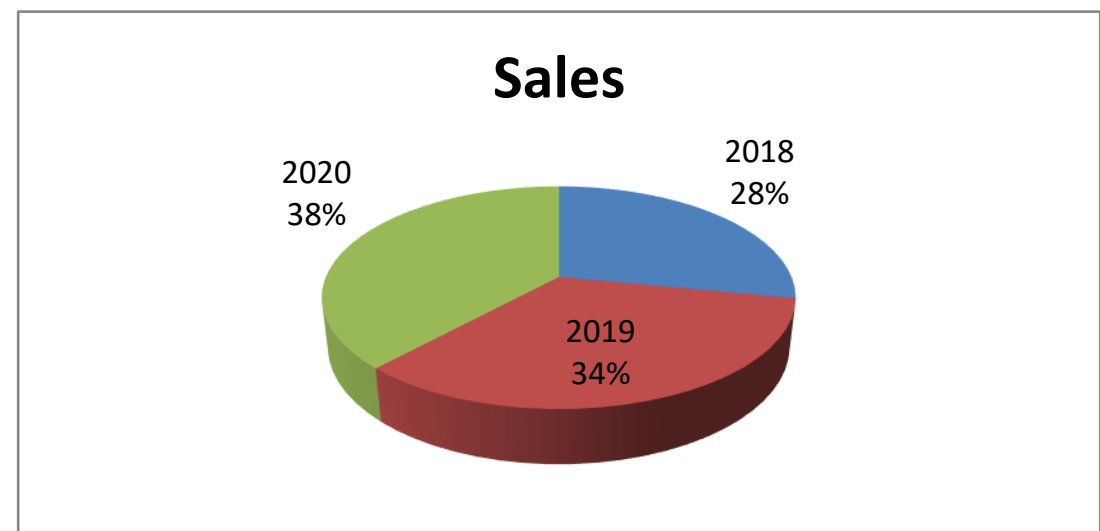

Grafik diatas menjelaskan tentang prsentase peningkatan UKM di Kabupaten bungo dari tahun 2018 sampai tahun 2019, dari tahun 2018 hingga 2019 jumlah UKM meningkat 5\% sedangkan dari tahun 2019 hingga tahun 2020 jumlah UKM meningkat lagi menjadi 4\%. Dari tahun 2018 hingga 2020 jumlah UKM dikabupaten Bungo terjadi peningkatan yang luar biasa dari tahun tahun sebelumnya, peningkatan itu yang paling menonjol yaitu terjadi pada tahun 2019, dimana ditahun 2018 yang sebelumnya hanya 2811 jenis UKM sedangkan ditahun 2019 menjadi 3387 atau lebih terjadi penembahan sebanyak 576 UKM (Wawancara, 7 juli 2020). Peningkatan jumlah UKM tersebut tersebar diseluruh kecamatan yang ada diwilayah kabupaten Bungo. Ditahun 2018 jumlah UKM berdasarkan pembagian kecamatan dapat dilihat pada tebel sebagai berikut

Tabel 5. Jumlah Pembagian UKM per Kecamatan Tahun 2018

\begin{tabular}{l|l|l|l|l|l} 
NO & KECAMATAN & \multicolumn{3}{|c}{ KLARIFIKASI USAHA UMKM } & \\
& & & & & \\
& & & & \\
1 & PIKRO & KECIL & MENENGAH & JUMLAH \\
2 & Bungo Dani & 173 & 69 & 23 & 410 \\
3 & Rimbo Tengah & 189 & 94 & 21 & 265 \\
4 & Bathin III & 120 & 24 & 14 & 304 \\
5 & Babeko & 77 & 52 & 10 & 158 \\
6 & Tanah Sepenggal & 85 & 43 & 9 & 139 \\
7 & Tanah Sepenggal Lintas & 120 & 83 & 9 & 137 \\
8 & Tanah Tumbuh & 72 & 29 & 7 & 212 \\
9 & Pelayang & 44 & 20 & 6 & 108 \\
10 & Limbur Lubuk Mengkuang & 40 & 17 & 6 & 70 \\
11 & Muko-Muko Bathin VII & 98 & 35 & 5 & 63 \\
12 & Rantau Pandan & 101 & 20 & - & 138 \\
13 & Bathin III ulu & 54 & 15 & 5 & 121 \\
14 & Jujuhan & 65 & 18 & 2 & 74 \\
15 & Jujuhan Ilir & 54 & 7 & 3 & 85 \\
16 & Pelepat & 107 & 30 & 3 & 64 \\
17 & Pelepat Ilir & 189 & 97 & 37 & 140 \\
& & 1.889 & 740 & 182 & 323 \\
& & & 2.811
\end{tabular}

Sumber : Dinas Kop, UMKM, Perindag kab. Bungo

Sedangkan data UKM di kabupaten Bungo tahun 2019 dapat dilihat pada tabel sebagai berikut: 
Tabel 6. Jumlah pembagian UKM per Kecamatan Tahun 2019

\begin{tabular}{l|l|l|l|l|l} 
No & Kecamatan & \multicolumn{3}{|l|}{ Klasifikasi Usaha UMKM } & Jumlah \\
1 & & Mikro & Kecil & Menengah & \\
2 & Pasar Muara Bungo & 487 & 93 & 27 & 607 \\
3 & Bungo Dani & 213 & 69 & 23 & 305 \\
4 & Rimbo Tengah & 192 & 94 & 21 & 307 \\
5 & Bathin III & 125 & 37 & 26 & 188 \\
6 & Tabeko & 77 & 52 & 25 & 154 \\
7 & Tanah Sepenggal & 85 & 48 & 26 & 159 \\
8 & Tanah Tumbuh & 120 & 83 & 9 & 212 \\
9 & Pelayang & 72 & 29 & 7 & 108 \\
10 & Limbur Lubuk & 44 & 20 & 14 & 78 \\
& Mengkuang & & 19 & 17 & 76 \\
11 & Muko-Muko Bathin VII & 98 & 57 & 15 & \\
12 & Rantau Pandan & 101 & 20 & 5 & 170 \\
13 & Bathin III ulu & 90 & 59 & 9 & 186 \\
14 & Jujuhan & 82 & 24 & 6 & 112 \\
15 & Jujuhan Ilir & 74 & 26 & 5 & 105 \\
16 & Pelepat & 127 & 54 & 18 & 199 \\
17 & Pelepat Ilir & 189 & 97 & 37 & 323 \\
& & 2.216 & 881 & 290 & 3.387
\end{tabular}

Sumber : Dinas kop, UMKM, Perindag Kab. Bungo

Untuk data UKM di Kabupaten Bungo pada tahun 2019 yang jumlahnya terjadi peningkatan dari tahun sebelumnya, dapat dilihat pada tabel sebagai berikut:

\begin{tabular}{|c|c|c|c|c|}
\hline \multirow[t]{2}{*}{ Kecamatan } & \multicolumn{3}{|c|}{ Klasifikasi Usaha UMKM } & \multirow[t]{2}{*}{ Jumlah } \\
\hline & Mikro & Kecil & Menengah & \\
\hline Pasar Muara Bungo & 497 & 105 & 32 & 634 \\
\hline Bungo Dani & 225 & 74 & 31 & 330 \\
\hline Rimbo Tengah & 192 & 94 & 21 & 307 \\
\hline Rimbo Tengah & 125 & 37 & 26 & 188 \\
\hline Babeko & 81 & 52 & 25 & 158 \\
\hline Tanah Sepenggal & 85 & 48 & 26 & 159 \\
\hline Tanah Sepenggal Lintas & 120 & 83 & 46 & 249 \\
\hline Tanah Tumbuh & 77 & 83 & 13 & 173 \\
\hline Pelayang & 57 & 43 & 20 & 120 \\
\hline Limbur Lubuk Mengkuang & 79 & 19 & 17 & 115 \\
\hline Muko-Muko Bathin VII & 98 & 57 & 15 & 170 \\
\hline Rantau Pandan & 101 & 72 & 17 & 190 \\
\hline Bathin III ulu & 90 & 59 & 19 & 158 \\
\hline Jujuhan & 82 & 61 & 22 & 165 \\
\hline Jujuhan Ilir & 83 & 33 & 16 & 132 \\
\hline Pelepat & 127 & 54 & 18 & 199 \\
\hline \multirow[t]{2}{*}{ Pelepat Ilir } & 197 & 109 & 68 & 374 \\
\hline & 2316 & 1083 & 432 & 3.821 \\
\hline
\end{tabular}




\section{Sumber : Dinas kop, UMKM, Perindag Kab. Bungo}

Pendataan jumlah UKM di Kabupaten Bungo merupakan tanggung jawab dari dinas Kopperindag, hal ini sesuai dengan pasal 8 ayat (1) peraturan Bupati Nomor 24 Tahun 2011 tentang Tugas Pokok dan Fungsi Dinas Koprasi, UMKM, Perindustrian dan Perdagangan Kabupaten Bungo, bahwa seksi permodalan dan hubungan kelembagaan UMKM mempunyai fungsi yang salah satu fungsinya adalah melaksanakan pembinaan dan penyaluran bantuan modal bagi usaha kecil dan menengah.Dalam melaksanakan pembinaan dan penyaluran bantuan modal bagi usaha kecil menengah, seksi permodalan dan hubungan kelembagaan UKM terlebih dahulu mendatangi UKM-UKM yang ada diKabupaten Bungo satu persatu dengan mencatat jenis UKM dan menanyakan kepada pemilik UKM tentang perkembangan UKM tersebut, dan pencatatan yang kami lakukan atau dilakukan secara rutin setiap tahunnya. Dari njaelasan ini, dapat disimpulkan bahwa Bidang UKM melalui seksi permodalan dan hubungan kelembagaan UKM melakukan pendataan dari UKM yang satu ke UKM yang lain, hal ini dengan tujuan untuk mengetahui perkembangan UKM yang ada di Kabupaten Bungo. Pasal 16 ayat 2 (a) peraturan Bupati Nomor 24 Tahun 2011 tentang Uraian tugas pokok dan fungsi Dinas Koperasi, UKM, perindustrian dan peerdagangan kabupaten bungo, bahwa seksi kelembagaan pada Bidang UKM Dinas Kopperindag hanya melakukan penyiapan serta pengelompokan data-data yang berkaitan dengan UKM.

Dalam melakukan pengelompokan-pengelompokan UKM yang ada di Kabupaten Bungo, salah satu dari seian banyak UKM adalah UKM Agribisnis. Sebagaimana dijelaskan pada BAB 1 diatas, perkembangan UKM Agribisnis tidak sama dengan perembangan UKM-UKM yang lain, dimana data terakhir UKM yang diperoleh hingga mencapai 3.821 UKM, sedangkan UKM Agribisnis hanya 14 yang tersebar kabupaten Bungo. Untuk lebih rinci mengenai perkembangan UKM Agribisnis sebagaimana dijelaskan diatas, dapat dilihat pada tabel sebagai berikut :

Tabel 8. Jumlah UKM Aribisnis diKabupaten Bungo 2018-2020

\begin{tabular}{l|l|l|l} 
No & Tahun & Jenis & Jumlah UKM Agribisnis \\
1. & 2018 & 3 & 10 \\
2. & 2019 & 3 & 14 \\
3. & 2020 & 3 & 14
\end{tabular}

Sumber : Dinas kop, UMKM, Perindag Kab. Bungo

Tabel diatas menunjukkan dari data UKM Agribisnis dari tahun 2018 terdapat 3 jenis UKM dan 10 jumlah UKM, ditahun 2019 hanya bertambah 4 UKM Agribisnis dengan jenis tetap 3 UKM Agribisnis, ditahun 2020 sama seperti ditahun sebelumnya, yaitu terdiri dari 3 jenis UKM Agribisnis, dan dengan jumlah 14 UKM Agribisnis, adapun 3 jenis UKM Agribisnis tersebut yaitu Pisang sale, Jamur tiram dan tahu tempe, untuk lebih lengkap mengenai data terkhir UKM Agribisnis yaitu pada tahun 2020, dapat dilihat seperti tertera pada tabel dibawah ini :

Tabel 9. Data Jumlah UKM Agribisnis Kabupaten di Kabupaten Bungo

\begin{tabular}{l|l|l} 
No & Nama UKM Agribisnis & \multicolumn{1}{|c|}{ Jumlah } \\
1 & Sale Pisang & 30 \\
2 & Jamur Tiram & 1 \\
3 & Tahu Tempe & 60
\end{tabular}

Tempat

Purwo Bakti,

Kec. Batin III

Kuamang Kuning

Candika, Rimbo

Tengah

Sumber: Dinas kop, UMKM, Perindag Kab. Bungo 


\section{Pelaksanaan Fungsi Dinas Kopperindag Dalam Pemberdayaan UKM Agribisnis-Kabupaten Bungo}

Fungsi menurut Kamus Lengkap Bahasa Indonesia merupakan kegunaan suatu hal, daya guna serta pekerjaan yang dilakukan. Adapun menurut The Ling Gie fungsi yaitu sekelompok aktivitas yang tergolong pada jenis yang sama berdasarkan sifatnya, pelaksanaan ataupun pertimbangan lainya. Definisi fungsi diatas mempunyai arti yang sama dengan definisi Sutarno, dimana Sutarno mendefinisikan bahwa yang dimaksud dengan Fungsi adalah rincian tugas yang sejenis atau erat hubungannya satu sama lain untuk dilakukan oleh seorang pegawai tertentu yang masing-masing berdasarkan sekelompok aktivitas sejenis menurut sifat atau pelaksanaanya. (Arifin, 2008)

Pendapat lain mengenai fungsi diutarakan oleh Franken, dimana menurut Franken, istilah fungsi secara yuridis mengandung makna yang berkaitan dengan urusan tugas. De, Haan, Druupsteen Frenhot yang dikutip oleh Kurniatmanto Soetoprowiro, mengemukakan bahwa "tugas" yang dilakukan oleh pemerintah melalui fungsi-fungsi Normatif, Fungsi Instrumental dan fungsi Pengayoman (Satoto, 2004). Sedangkan di dalam peraturan Pemerintah Nomor 58 Tahun 2005 tentang Pengolahan Keuangan Daerah, bahwa yang dimaksud dengan Fungsi adalah perwujudan tugas kepemerintahan dibidang tertentu yang dilaksanakan dalam rangka mencapai tujuan pembangunan nasional.

Erat kaitannya dengan pemberdayaan UKM Agribisnis merupakan bagian dari tugas dan fungsi Dinas Kopperindag, dalam pasal 1 Peraturan Daerah Kabupaten Bungo Nomor 01 Tahun 2011 tentang Pembentukan dan susunan Organisasi Dinas Daerah dijelaskan bahwa Dinas Kopprindag mempunyai tugas melaksanakan urusan pemerintahan daerah berdasarkana asas otonomi dan tugas pemantauan dibidang koeprasi, UKM, perindustrian dan perdagangan. Di ayat 2 nya dijelaskan, bahwa Dinas Koperasi, UKM, Perindustrian dan Perdagangan dalam menjalankan tugasnya, mempunyai fungsi :

a. Perumusan kebijakan teknis dibidang Koperasi, UKM, Perindustrian dan perdagangan.

b. Penyelenggaraan urusan pemerintahan dan pelayanan umum dibidang Koperasi, UMKM, Perindustrian dan perdagangan.

c. Pelaksanaan koordinasi dan kerja sama dengan instansi terkait di bidang Koperasi, UKM, Perindustrian dan Perdagangan,

d. Pembinaan, pengawasan, pengendalian dan evaluasi terhadap pelaksanaan tugas dibidang Koperasi, UKM, Perindustrian dan Perdagangan.

e. Pembinaan terhadap UPTD.

f. Pemberian saran dan pertimbangan serta menyampaikan laporan, hasil telaahan dan analisa kepada atasan dengan tugas pokok dan fungsinya.

g. Pelaksanaan tugas lain yang diberikan oleh Bupati.

Terlihat secara jelas bahwa Dinas Kopprindag selalu melaksanakan sesuai dengan fungsi yang ditetapkan oleh peraturan daerah tersebut, bahkan dalam melaksanakan kegiatan, Dinas Kopprindag berkoordinasi dengan instansi terkait, sesuai dengan salah satu fungsi dinas Kopperindag dalam pasal 1 ayat 2 huruf c peraturan DaerahKabupaten Bungo Nomor 01 Tahun 2011 bahwa dinas Kopperindag melakukan pelaksanaan koordinasi dan kerjasama dengan instansi terkait dibidang Koperasi, UKM, Perindustrian dan Perdagangan. Dilihat dari pasal 15 ayat (1) Peraturan Bupati Nomor 24 Tahun 2011 bahwa seksi Kelembagaan UKM mempunyai tugas pokok menyiapkan dan menyusun bahan penghimpunan, 
penyusunan, pengkoordinasian, pelaksanaan program pemberdayaan UKM, disektor kelembagaan serta menganalisa, mengevaluasi dan melaporkan seluruh kegiatan seksi kelembagaan UKM kepada Kepala Dinas Bidang Usaha Kecil Menengah.

Sedangkan dalam pasal 15 ayat (2) Peraturan Bupati Nomor 24 Tahun 2011, dalam menjalankan tugas seksi Kelembagaan UKM mempunyai fungsi:

a. Menyiapkan data UKM sebagai bahan pembinaan dalam rangka penerangan, penyuluhan, pelatihan magang.

b. Penyusunan rencana dan program pemberdayaan UKM, dibidang kelembagaan.

c. Penyiapan bahan koordinasi data ukm, dengan unit kerja lain dan instansi terkait untuk menciptakan keterpaduan program dan keseragaman data.

Pasal 15 Peraturan Bupati Nomor 24 Tahun 2011 tersebut tidak menjelaskan bahwa Dinas Kopperindag mempunyai kewajiban melakukan pendataan UKM secara langsung kelapangan, melainkan hanya menyiapkan data yang suda ada untuk melakukan penyuluhan, pembinaan dan magang.

Dinas kopperindag sudah menerapkan strategi agar data UKM yang salah satunya UKM Agribisnis benar-benar akurat sesuai dengan kenyataan dilapangan, dengan tujuan mempermudah pembinaan UKM Agribisnis tersebut, hal ini sesuai dengan yang dijelaskan dalam Peraaturan Bupati Nomor 24 Tahun 2011 bahwa seksi kelembagaan mempunyai fungsi penyiapan data UKM sebagai bahan pembinaan dalam rangka penerangan, penyuluhan, pelatihan dan magang.

Erat kaitannya dengan pembinaan dan pemberdayaan, dari Dinas Kopperindag sudah sering melakukan pembinaan dan pemberdayaan UKM agribisni. Menurut Prasetyo tujuan adanya usaha pembinaan dan pengembangan UKM antara lain:

a. Meningkatkan akses pasar dan memperbesar pangsa pasar.

b. Meningkatkan akses terhadap sumber-sumber modal dan memperkuat struktur modal.

c. Meningkatkan kemampuan organisasi dan manajemen, dan

d. Meningkatkan akses dan penguasaan teknologi. (Prasetyo, 2008)

Sedangkan dalam pasal 5 Undang-Undang Nomor 20 tahun 2008 tentang Usaha Kecil Menengah bahwa tujuan pemberdayaan Usaha Kecil, dan Menengah antara lain :

a. Mewujudkan struktur perekonomian nasional yang seimbang, berkembang, dan berkeadilan.

b. Menumbuhkan dan mengembangkan kemampuan Usaha Kecil Menengah menjadi usaha yang tangguh dan mandiri, dan

c. Meningkatkan peran Usaha Menengah dalam pembangunan daerah, penciptaan lapangan kerja, pemerataa pendapatan, pertumbuhan ekonomi, dan pengentasan rakyat dari kemiskinan.

Keberadaan UKM Agribisnis Di Kabupaten Bungo sangat membantu pertumbuhan perekonomian daerah, setidaknya menambah lapangan pekerjaan, dengan UKM Agribisnis yang jumlahnya hingga mencapai 14 setidaknya lebih kurang 60 orang mendapatkan pekerjaan. 
Tabel 10. Jumlah Karyawan UKM Agribisnis Tahun 2018 Tahun 2020

\begin{tabular}{l|l|l} 
NO & Nama UKM Agribisnis & Jumlah Karyawan \\
1. & Sale Pisang & 138 \\
2. & Jamur Tiram & 9 \\
3. & Tahu Tempe & 252
\end{tabular}

Sumber : Dinas kop, UMKM, Perindag Kab. Bungo

Data diatas sebagai bukti dengan keberadaan UKM Agribisnis membantu pertumbuhan perekonomian yang ada di Kabupaten Bungo. Mengenai pemberdayaan terhadap UKM Agribisnis dilakukan secara rutin baik oleh pemerintah daerah sendiri bahkan swasta. Kegiatan tersebut terkait dengan bantuan rutin pada UKM Agribisnis baik berupa bimbingan, penyuluhan, pelatihan, bantuan modal, maupun bantuan peralatan. Pemberdayaan yang dilakukan meliputi:

1. Bimbingan dan Penyuluhan

Kegiatan bimbingan dan penyuluhan dilakukan oleh pemerintah Aparat dari Dinas Kopprindag Kabupaten Bungo mendatangi pemilik UKM agribisnis di Kabupaten Bungo. dalam hal ini, aparat Dinas Kopprindag bertemu langsung dan saling bertukar informasi mengenai masalah UKM Agribisnis dengan para pemilik UKM sehingga aparat Dinas mengetahui bagaimana perkembangan UKM tersebut serta masalah-masalah yang ditemui oleh para pengusaha. Aparat Dinas Kopprindag akan memberikan informasi dan masukan mengenai upaya-upaya apa yang bisa dilakukan untuk mengembangkan UKM Agribisnis. Kegiatan bimbingan dan penyuluhan dilakukan sewaktu-waktu, tidak secara rutin terjadwal. Hal itu dikarenakan banyaknya jumlah pengusaha tidak diimbangi dengan banyaknya jumlah aparat Dinas. Pada saat mendatangi pemilik UKM Agribisnis itulah, aparat Dinas Kopperindag berbagai cerita dengan para pekerja dan pemilik UKM. Dan para pemilik UKM Agribisnis juga tidak ragu untuk menceritakan masalah yang mereka jumpai. Sebenarnya kedatangan aparat Dinas Kopprindag sangat diharapkan oleh para pemilik UKM Agribisnis.

\section{Pendidikan dan pelatihan}

Selain berupa kegiatan bimbingan dan penyuluhan dari pemerintah daerah yang dalam hal ini adalah dinas Kopperindag Kabupaten Bungo, juga diadakan kegiatan pendidikan dan pelatihan. Kegiatan ini dilakukan untuk menambah wawasan dan pengetahuan para pengusaha atau pemilik UKM Agribisnis sehingga kemampuan wirausaha mereka akan meningkat.

\section{Bantuan Pengembangan}

Selain penyuluh dan pelatihaan, bentuk pembinaan dan pengembangan pada UKM Agribisnis, Dinas Kopperindag juga melakukan pemberian bantuan pengembangan. Pada umumnya, bantuan pengembangan bukan hanya dilakukan oleh pemerintah pusat, propinsi dan kabupaten, tetapi ada juga dilakukan oleh pihak swasta, Namun demikian dalam pelaksanaannya tetap melibatkan pemerintah. Dinas kopperindag mempunyai program bantuan dan pengembangan UKM yang ada di Kabupaten Bungo, diantara UKM-UKM yang ada, termasuk UKM yang bergerak dibidang agribisnis, dimana Dinas 
Kopperindag pernah memberikan peralatan-peralatan untuk kebutuhan para UKM Agribisnis, baik itu kuali, kompor, dan banyak peralatan-peralatan yang lain sesuai dengan kebutuhan UKM tersebut.

Pernyataan bapak Fori sudah sedikit puas dengan program yang dilakukan oleh Dinas Kopperindag kabupaten Bungo, dimana selaku pemilik UKM Agribisnis yang secara tidak langsung membantu perekonomian Kabupaten Bungo, dimana selama perjalanan UKM Agribisnis miliknya banyak bantuan yang dilakukan oleh pemerintah daerah. Dilihat pada pasal 17 Perbup 24 tahun 2011 bahwa seksi Permodalan dan Hubungan kemitraan UKM mempunyai tugas pokok menyusun, mengelompokkan, mengolah melakukan koordinasi, memfasilitasi dan melaksanakan kebijakan teknis dibidang pengembangan UKM.

Dilihat dari penjelasan peraturan Bupati Nomor 24 tersebut, Seksi permodalan bertanggung jawab dalam koordinasi pemberian bantuan kepada para pemilik UKM Agribisnis, baik bantuan yang diberikan oleh pemerintah pusat, pemerintah daerah propinsi, pemerintah daerah Kabupaten dan bahkan pihak swasta.

\section{Faktor-Faktor Penghambat Pelaksanaan Fungsi Dinas Kopperindag Dalam Pemberdayaan UKM Agribisnis di Kabupaten Bungo}

Seperti dibahas pada bab sebelumnya, perkembangan UKM Agribisnis di Kabupaten Bungo tidak seimbang dengan jumlah UKM secara keseluruhan, dimana jumlah UKM yang ada di Kabupaten Bungo hingga mencapai 3.821 UKM sedangkan jumlah UKM agribisnis di Kabupaten Bungo hanya 14 UKM. Sedangkan dilihat dari potensi daerah Kabupaten Bungo yang sebagian besar daerah pertanaian dengan kata lain Sumber Daya Alam (SDA), secara geografis mendukung tentang perkembangan UKM Agribisnis di Kabupaten Bungo.

Dalam undang-undang UKM ada bentuk kewajiban Pemerintah dan Pemerintah Daerah dalam melakukan pengembangan dan pemberdayaan UKM. yang dimaksud dengan pengembangan UKM dalam pasal 1 ayat 10 dan 11 UndangUndang UKM adalah upaya yang dilakukan oleh pemerintah, Pemerintah daerah, Dunia usaha, dan masyarakat untuk memberdayakan Usaha Kecil dan Menengah melalui pemberian fasilitas, bimbingan, pendampingan, dan bantuan kekuatan untuk menumbuhkan dan meningkatkan kemampuan dan daya saing Usaha Kecil dan Menengah. Dalam bentuk pengembangan, tidak terlepas dari pembiayaan, yang dimaksud dengan pembiayaan adalah penyediaan dana oleh pemerintah, Pemerintah Daerah, Dunia Usaha dan masyarakat melalui bank, Koprasi dan lembaga keuangan bukan bank, untuk mengembangkan dan memperkuat permodalan Usaha Kecil dan Menengah.

Sedangkan dalam pasal 15 ayat (2) huruf d peraturan Bupati Kabupaten Bungo Nomor 24 Tahun 2011 tentang Uraian Tupoksi Dinas Kopperindag bahwa saksi kelembagaan UKM mempunyai fungsi penyiapan bahan perangkaan stastistik UKM, sebagai bahan untuk merumuskan rencana dan program pemberdayaan UKM, berprestasi. Dalam pelaksanaan pemberdyaan UKM Agribisnis, Pemerintah Kabupaten Bungo melalui Dinas Kopperindag belum ada melaksanakan fungsi pemberdayaan UKM yang khusus terhadap UKM Agribisnis yang berprestasi, Padahal dilihat dari 3 jenis UKM Agribisnis yang ada di Kabupaten Bungo, salah satu nya UKM Agribisnis tersebut UKM Unggulan pemerintah Kabupaten Bungo yaitu UKM sale pisang, seharusnya pemerintaah Kabupaten Bungo terhadap UKM yang berprestasi benar-benar dilakukan pembinaan. Padahal di pasal 16 huruf c peraturan Bupati Nomor 24 Tahun 2011menyatakan salah satu fungsi seksi menajemen UKM yaitu penyiapan data UKM yang mempunyai produk unggulan di berbagai sektor usaha. Adapun penyebab kurang berkembangny UKM Agribisnis di 
Kabupaten Bungo yaitu tidak adanya penyuluhan yang diberikan oleh Dinas Kopperindag kepada masyarakat umum

Pernyataan ibu Ir. Yurnita sesuai dengan tugas pokok dan fungsi Dinas Kopperindag dalam peraturan Bupati Nomor 24 Tahun 2011 karena dalam peraturan tersebut tidak membicarakan kewajiban Dinas Kopperindag memberikan penyuluhan dan pembinaan kepada masyarakatumum. Namun dilihat secara jelas dalam Peraturan Bupati tersebut juga menjelaskan bahwa Dinas Kopperindag mempunyai kewajiban berkoordinasi dengan instansi lain, dalam hal memberikan penyuluhan dan pembinaan UKM Agribisnis, seharusnya dinas kopperindag melaksanakan koordinasi dengan Dinas Ketenagakerjaan atau Dinas pembidangan pertanian.

\section{Penutup}

Setelah melakukan penelitian tentang Fungsi Dinas Koperasi, UKM, Perindustrian dan Perdagangan dalam pemberdayaan Usaha Kecil Menengah Agribisnis di Kabupaten Bungo, maka yang dapat disimpulkan penelitian antara lain 1) Kondisi UKM Agribisnis di Kabupaten Bungo. Jumlah UKM di Kabupaten Bungo tahun 2018 sebanyak 2.811, Tahun 2019 sebanyak 3.387 dan ditahun 2020 sebanyak 3.821 UKM, sedangkan UKM Agribisnis ditahun 2018 sebanyak 10 UKM, Tahun 2019 sebanyak 14 UKM dan ditahun 2020 sebanyak 14 UKM. Dilihat perkembangan UKM Agribisnis di Kabupaten Bungo tidak seimbang dengan jumlah UKM secara keseluruhan, dimana jumlah UKM yang ada dikabupaten bungo hingga mencapai 3.821 UKM sedangakan jumlah UKM Agribisnis di Kabupaten Bungo hanya $14 \mathrm{UKM}$, sedangkan dilihat dari potensi daerah Kabupaten Bungo yang sebagian besar daerah pertanian dengan kata lain Sumber Daya Alam (SDA) secara geografis. 2) Pelaksanaan Fungsi Dinas Kopperindag Dalam Pemberdayaan UKM Agribisnis di Kabupaten Bungo memiliki beberapa kegiatan yaitu a. Bimbingan dan Penyuluhan. Kegiatan bimbingan dan penyuluhan oleh petugas Dinas Kopperindag dilakukan dengan cara mendatangi pemilik UKM Agribisnis untuk bertemu langsung dan saling bertukar informasi mengenai masalah UKM Agribisnis dengan para pemilik UKM. kegiatan bimbingan dan penyuluhan dilakukan sewaktu-waktu, tidak secara rutin terjadwal. Hal itu dikarenakan banyaknya jumlah pengusaha tidak membimbing dengan banyaknya jumlah pengusaha tidak diimbangi dengan banyaknya jumlah aparat Dinas; b. Pendidikan dan Latihan. Kegiatan pendidikan dan latihan ditujukian untuk menambah wawasan dan pengetahuan para pemilik UKM Agribisnis sehuingga kemampuan wirausaha mereka akan meningkat. Kegiatan pendidikan dan pelatihan berupa seminar atau workshop dilanjutkan dengan praktek. Kegiatan pendidikan dan pelatihan tidak hanya dilaksanakan di Kabupaten bungo tetapi juga dilaksanakan diluar daerah; c. Bantuan pengembangan.Dinas Kopperindag selalu melakukan pemberian bantuan pengembangan, bantuan pengembangan bukan hanya dilakukan oleh pemerintah pusat, propinsi dan kabupaten, tetapi ada juga dilakukan oleh pihak swasta. Bantuan pengembangan yang dilakukan pemerintah daerah yaitu dengan memberikan modal, pinjaman lunak dan memberikan peralatan-peralatan untuk kebutuhan para UKM Agribisnis, (seperti Kuali, kompor, dan peralatan-peralatan yang laian sesuai dengan kebutuhan UKM). 3) Faktor Penghambat Pelaksanaan Fungsi Dinas Kopperindag Dalam Pemberdayaan UKM Agribisnis di Kabupaten Bungo diantaranya a. Dinas kopprindag hanya melakukan penyuluhan dan pembinaan kepada pemilik UKM dan tidak Zilaksanakan penyuluhan kepada masyarakat umum, sehingga mesyarakat umum masih minin berfikir tentang upaya melakukan pengembangan UKM Agribisnis; b. Masih kurangnya koordinasi antara Dinas Koperasi, UKM, perindustrian dan perdagangan dengan instansi-instansi pemerintah daerah yang lain, seperti Dinas ketenaga kerjaan dan Dinas yang membidangi masalah pertanian; c. Terbatas nya aparat dari Dinas Koperasi, UKM, 
Perindustrian dan Perdagangan, sedangkan UKM yang ada di Kabupaten Bungo bukan hanya UKM Agribisnis saja yang harus dlakukan pembinaan.

Selanjutnya terdapat beberapa saran yaitu 1) diharapkan mahasiswa dari berbagai perguruan tinggi yang ada di Kabupaten Bungo untuk membentuk Forum Komunikasi BEM se-Kabupaten Bungo agar mudah melakukan konsolidasi saat akan ada aksi tuntutan mahasiswa, 2) perlu adanya dukungan dari seluruh elemen kampus untuk mendukung dan mendorong mahasiswa sebagai agen perubahan.

\section{Referensi}

Arifin, Z. (2008). Metodelogi Penelitan Pendidikan. Lentera Cendekia.

Kristiyanti, M. (2012). Peran strategis usaha kecil menengah (UKM) dalam pembangunan nasional. Majalah Ilmiah Informatika, 3(1), 63-89.

Moenir. (2001). Manajemen Pelayanan Umum Di Indonesia. Bumi Aksara.

Prasetyo, A. (2008). Analisis Pengaruh Kualitas Pelayanan Terhadap Kepuasan Nasabah BMT.

Satoto, S. (2004). Pengaturan Eksistensi dan Fungsi Badan Kepegawaian Negara.

Seymour, R., \& Turner, S. (2002). Otonomi daerah: Indonesia's decentralisation experiment. New Zealand Journal of Asian Studies, 4, 33-51.

Widjaja, H. (2008). Otonomi Desa: Meruapakan otonomi Yang Asli Bulat dan Utuh. Rajawali Pers. 